\title{
Bola Fúngica após ocorrência de Tuberculose em Paciente Alcoolista: Relato de Caso
}

\author{
Tornatore, A.R.; Jornada, F.M.;
}

Apresentador: Angela Rosa Tornatore

\section{Resumo}

Introdução: O aspergiloma pulmonar, também chamado bola fúngica $(\mathrm{BF})$, consiste de massa fúngica, muco, sangue, células inflamatórias e resíduos celulares em uma cavidade. Associa-se à doença pulmonar pregressa, em geral tuberculose pulmonar (TB), que promove a formação dessas cavidades no parênquima, suscetíveis à colonização fúngica. Essa colonização ocorre devido à fibrose pericavitária e a epitelização endocavitária, que dificultam a fagocitose dos propágulos fúngicos e também ao muco sobre o epitélio brônquico, que gera o meio de cultivo. A bola fúngica tem como agente etiológico predominante o Aspergillus fumigatus e o tratamento de escolha é cirúrgico. Relato do Caso: J.A.V., 53 anos, pescador, alcoolista de longa data, tabagista, com história de tuberculose pulmonar prévia tratada por 12 meses, queixando dor torácica e dispneia, associada à tosse com expectoração esbranquiçada, perda de peso e hemoptise. Ao exame apresentava murmúrio vesicular diminuído bilateral e sibilos difusos. Investigou-se nova TB, com resultado de teste de BAAR negativo em 3 culturas de escarro (repetido e novamente confirmado como negativo). Realizou RX de tórax, com evidência de DPOC e Tomografia (TC) de tórax, que evidenciou imagem cavitada no ápice do pulmão esquerdo apresentando pequena área isodensa em seu interior $(13 \mathrm{~mm}$ de diâmetro) sugestiva de bola fúngica complexa, com parênquima adjacente apresentando estrias fibro-atelectásicas. Procedeu-se ao tratamento com Itraconazol e o paciente foi encaminhado a procedimento cirúrgico (lobectomia superior esquerda) com confirmação do diagnóstico através de avaliação micológica realizada em material coletado durante procedimento cirúrgico, com detecção ao exame direto de hifas septadas e ramificadas em arranjo de $\mathrm{BF}$, e A. fumigatus isolado em cultura. Discussão: $\mathrm{O}$ etilismo é um dos fatores de redução da imunocompetência sistêmica, assim como a pré-existência de TB e DPOC. Embora a TB seja o principal fator para o surgimento de colonização fúngica em cavidade saneada, a coexistência das duas doenças é rara. Mesmo assim, realizou-se teste de BAAR devido à forte suspeita clínica. Só foi possível a suspeita diagnóstica após a TC de tórax, quando então se iniciou terapia antifúngica, mas estudos indicam que após a formação da BF, esta é ineficiente, pois as drogas não atingem os fungos dentro da cavidade. A terapia de escolha, então, principalmente quando há história de hemoptise, é a ressecção do pulmão acometido ou de parte dele

\section{Referência:}

Tornatore, A.R.; Jornada, F.M.;. Bola Fúngica após ocorrência de Tuberculose em Paciente Alcoolista: Relato de Caso. In: II Congresso Brasileiro de Medicina Hospitalar - II CBMH [= Blucher Medical Proceedings, vol.1, num.5] São Paulo: 